\title{
HISTORIC AND CONSTRUCTIONAL ASPECTS OF STONE SCHOOLS IN GREECE: THE CASE OF THE ARISTOTLE MUNICIPALITY IN CHALKIDIKI
}

\author{
Vasiliki PACHTA (1)* \\ Laboratory of Building Materials, School of Civil Engineering, Aristotle University of Thessaloniki, \\ Thessaloniki, Greece
}

Received 14 January 2021; accepted 27 August 2021

\begin{abstract}
Historic schools, built during the end of the $19^{\text {th }}$ - beginning of the $20^{\text {th }}$ century, were evolved according to the wider socio-economic changes that took place at regional, national and international level. Their construction usually followed specific principles, governed by their functional role and structural safety requirements. In this study, the historical background of school buildings in Greece is given, in an effort to assess their evolution and physiognomy. To this direction, 14 historic school buildings, located in the Aristotle Municipality of Chalkidiki, N. Greece, were studied, taking into account their architectural and constructional characteristics. These buildings were erected from 1871 up to 1958 and are nowadays mostly used as elementary schools. In some cases, they are in second use or abandoned. They concerned 1 up to 3 storeys buildings, with rectangular ground plan, symmetrically organized around a main corridor. Their size and dimensions varied according to their capacity. From the beginning of the 30's, supplementary elements of reinforced concrete (slabs, beams) were added, in combination with the existing building techniques. Nowadays, they are generally preserved in good state, due to the consecutive interventions taken place during their service life. However, their documentation and identification as heritage structures should be further assessed, in order to convey the tangible and intangible values they incorporate in the next generations.
\end{abstract}

Keywords: stone schools, educational centers, restoration, monuments, architectural heritage.

\section{Introduction}

The evolution of school buildings may be directly linked to various parameters, such as the educational history of each country, the cultural background, the general socioeconomic conditions, as well as the diachronic principles followed in constructions (Watters, 2020; Guarini et al., 2020; Galimullina \& Korotkova, 2020; García, 2020; Abreu Marques et al., 2015; Augustinaité, 2018; Broekhuizen et al., 2020). Their erection started to be systemized during the $19^{\text {th }}$ century, while in the past eras, education was mostly conducted in private houses, public or religious buildings (Abreu Marques et al., 2015; Watters, 2020; Martinez-Molina et al., 2017; Dascalaki \& Sermpetzoglou, 2011; Atkins, 1999; Camacho-Montano et al., 2020). To this direction, the national educational policies played an important role, as well as the establishment of a stable educational system in each state (Watters, 2020; Guarini et al., 2020; Martinez-Molina et al., 2017; Lerma et al., 2013; Broekhuizen et al., 2020).
Nowadays, there is a great stock of stone school buildings at National and European level (Abreu Marques et al., 2015; Watters, 2020; Guarini et al., 2020; Galimullina \& Korotkova, 2020; Martinez-Molina et al., 2017; Dascalaki \& Sermpetzoglou, 2011; Arya, 1987; Lassandro et al., 2015; Perrone et al., 2020; Doukas \& Bruce, 2017; Buvik et al., 2014; Khledj \& Bencheikh, 2021; Camacho-Montano et al., 2020; Pachta et al., 2021) that are either still in function (as schools or in a secondary use) or abandoned. In many cases, historic school buildings have been demolished due to their abandonment and the severe damages they confronted. Buildings, especially those located around the Mediterranean basin (Italy, Spain, France, Greece) present several structural and architectural similarities, since they have been mainly erected in a period of 50 years (end of the $19^{\text {th }}$ - beginning of the $20^{\text {th }}$ century), according to the traditional constructional techniques and by using local raw materials (Martinez-Molina et al., 2017; Perrone et al., 2020; Buvik et al., 2014; Carofilis et al., 2020; Khledj \& Bencheikh, 2021; Lerma et al., 2013; Pachta et al., 2021).

${ }^{*}$ Corresponding author. E-mail: vpachta@civil.auth.gr 
Their morphology and decoration could vary, according to the architectural style adopted (rural, Neoclassic, Eclectistic), whilst the outlines of their structure followed the principle of functionality (Abreu Marques et al., 2015; Khledj \& Bencheikh, 2021; Lerma et al., 2013; Carofilis et al., 2020; Perrone et al., 2020; Camacho-Montano et al., 2020). Floor plans were usually rectangular and symmetric, regarding both the organization of the inner spaces and the distribution of the openings (Arya, 1987; Martinez-Molina et al., 2017; Lassandro et al., 2015; Perrone et al., 2020; Doukas \& Bruce, 2017). Special attention was given to the proper orientation of the building, as well as the type and size of the openings, in order to achieve natural ventilation and lighting (Arya, 1987; Martinez-Molina et al., 2017; Lassandro et al., 2015; Perrone et al., 2020).

According to recent studies, there is a great interest on the assessment of energy efficiency (Martinez-Molina et al., 2017; Dascalaki \& Sermpetzoglou, 2011; Khledj \& Bencheikh, 2021; Lassandro et al., 2015; Buvik et al., 2014; Camacho-Montano et al., 2020) and seismic risk (Arya, 1987; Perrone et al., 2020; Carofilis et al., 2020) of historic school buildings. This could be related to their use, since most of them are still in function as elementary or secondary schools and therefore their energy performance and structural integrity are of primary importance. However, there are limited studies regarding the evolution, historic background and technological aspects of these structures, although some of them have been listed and identified as cultural assets (Dascalaki \& Sermpetzoglou, 2011; Khledj \& Bencheikh, 2021; Pachta et al., 2021).

Additionally, these buildings encompass significant intangible assets that need to be promoted and preserved, related to the educational evolution and history of each state, as well as the principles and memories they enclose (Avrami et al., 2000; Douglas-Jones et al., 2016; Lee et al., 2019; Pachta et al., 2021). Their establishment may be linked with the Enlightenment perspectives predominating Europe during the $18^{\text {th }}-19^{\text {th }}$ century, as well as the wider socio-economic changes that took place at that period. The privilege of education gradually became a human right, protected by each Nation, while it was transformed to a public good (François, 1968). The Universal Declaration of Human Rights (1948) elucidated the right to education, proclaiming that Education should be free and compulsory, focusing on the development of the human personality and strengthening its fundamental freedoms (United Nations General Assembly, 1948).

To this direction, the priorities of schools started to encompass (apart from the main educational and constructional needs) additional ethics, such as the freedom of knowledge and speech, social equality, fraternity etc. (François, 1968). School was therefore transformed to a close and protective community, engaged with the development of citizens (according to the democratic ideals), which even nowadays remains a great debate.

In this study, an effort has been made to record the evolution of school buildings in Greece, focusing on those erected during the end of the $19^{\text {th }}-$ middle $20^{\text {th }}$ century, in the Aristotle Municipality, Chalkidiki peninsula, N. Greece. The studied buildings concern stone masonry structures that were built as schools and are still maintained, or have a secondary use. The area was selected since it is a mountainous part of Greece, with long-term history, located near to the city of Thessaloniki. As has been documented, the constructional principles of regional school buildings in Greece follow the traditional building techniques up to the middle of the $20^{\text {th }}$ century, whereas in the city centers they were abandoned from the 30 's.

The aim of the study, was to define the historic, architectural and constructional characteristics, of the stone schools of the specific area, as well as to detect their preservation state. From the correlation of the results, the similarities and differences of their morphological and structural aspects arose, as well as the functionality of their design that predominated their facades.

\section{The evolution of school buildings in Greece}

In Greece, the educational space and system was formed from ancient times ( $5^{\text {th }}$ cent. BC), mostly oriented to males and starting from the age of six (primary education) (Freeman, 1912). The secondary education followed and afterwards the tertiary one (Freeman, 1912). During the last centuries, the educational system confronted many changes, while in the $17^{\text {th }}-18^{\text {th }}$ century, schools were mainly hosted at private houses, churches or monasteries (Kalafati, 1988). Education was closely related with religion, whereas tutors were mostly priests or monks (Kalafati, 1988).

At the end of the $18^{\text {th }}$ century, the first school buildings started to be constructed, following the ecclesiastical building technology, such as the school of Palamas in Mesologgi (1760) and the school of Dimitsana in Peloponnesus (1764). These buildings met the basic educational requirements, comprising of two rectangular spaces, while the most popular schools had also libraries and boarding houses (Kalafati, 1988). According to tradition, schools were usually attached or neighboring to religious buildings (monasteries, churches), or outside the settlements, for achieving isolation and meditation (based on the monastic principles) (Kalafati, 1988; Lerma et al., 2013; Pachta et al., 2021). The organization of the inner spaces was introverted, often developed in two floors around a courtyard, while the building type was influenced by the traditional mansion house (" $\alpha \rho \chi o v \tau \imath \kappa o ́ ") ~(K a l a f a t i, 1988)$.

During the Greek War of Independence (1821), education seems to be a primer goal. In the first Constitution of the Greek State (1823) it was declared that education was public and under the responsibility of the parliament, while in 1824 a National Education strategy was developed (Kokkonis, 1831; Moraitis, 1880; Kalafati, 1988). Three educational levels were established (primary, secondary, University) and school buildings started to be constructed, following the traditional principles. Soon after (1831), the first specifications for the school buildings were published by Kokkonis (1831), influenced by the initiatives of the 
French Society for Elementary Instruction (mutual educational system) (Tipei, 2017).

According to the French standards, the mutual school referred to a distinct building composed by a large rectangular classroom (according to the students' number) and a courtyard, while the structure was located in the central part of the settlement (in a distance from the road for achieving privacy) (Kokkonis, 1831). Posterior (1833-1839) guidelines and legislative frames (Kalafati, 1988), provided more detailed information regarding their construction (elevated ground floor with a basement), as well as the openings (large windows put opposite in the elongated sides for natural lighting and ventilation).

Generally, the building type was simple, according to the traditional building techniques and with materials of local origin (stones, lime-based mortars, wood), while during 1870-80 the ground plan became more complex with an increase on the inner spaces (Kalafati, 1988). In 1881, the book of Moraitis (1880) became the National Standard for school buildings (until 1894) (Kalafati, 1988). According to Moraitis (1880), schools should be located in the center of the settlements, in the back side of a courtyard (of double the size of the building), surrounded by a high wall (for sound insulation). Each classroom should have a capacity of 60-70 students (in towns) to 80-90 (in villages), with a total size varying from $50-70 \mathrm{~m}^{2}$ to $60-90 \mathrm{~m}^{2}$ respectively $\left(0.9-1.25 \mathrm{~m}^{2}\right.$ /student) and have a rectangular plan (6.5-7×10-12 m) (Figure 1a). The orientation of the building should be Southern, the height 4-5 $\mathrm{m}$ and the floor wooden (Moraitis, 1880). There were many consecutive windows (for proper lighting and ventilation) of dimensions $(\mathrm{b} \times \mathrm{h}) 1-1.5 \times 2-3 \mathrm{~m}$.
The first national program of school buildings' construction was legislated in 1894 (based on the co-teaching educational scheme, edited by the Mechanic D. Kallias), where specific instructions on the structure and morphology of school buildings were given (Hellenic Polytechnic Society, 1906; Kardamitsi-Adami, 1986; Pantazis, 2010). Natural lighting and ventilation was a crucial aspect to be taken into account, while the constructional types and materials were described in detail. The classroom's size was based on Moraitis (1880) and could be repeated according to the total number of the students, while the inner spaces were arranged symmetrically around the main corridor (which was connected with the entrance), with a repetition of the ground plan in the first floor (Figure 1b) (Hellenic Polytechnic Society, 1906; Kardamitsi-Adami, 1986; Pantazis, 2010). The external walls (stone masonry) should be $60 \mathrm{~cm}$ thick, with the inner ones to be $50 \mathrm{~cm}$ (for brick masonry the thickness was at least $35 \mathrm{~cm}$ ) (Hellenic Polytechnic Society, 1906; Kardamitsi-Adami, 1986). The floor slab was made of wood or concrete (elevated around $60 \mathrm{~cm}$ from the ground) and the floor height was at least 4m (Hellenic Polytechnic Society, 1906; Kardamitsi-Adami, 1986). The openings were large (rectangular or slightly arched) and symmetrically put on the left side of the rooms, while the main façade was decorated according to the Neoclassicism principles (frames, reliefs, pediment, colonettes, cornices). Until the year 1906 around 400 school buildings were erected, constituting the $11 \%$ of the National schools of the era (Kalafati, 1988; KardamitsiAdami, 1986).

In 1929, a legislative reform in education was realized, according to which the existing school types were
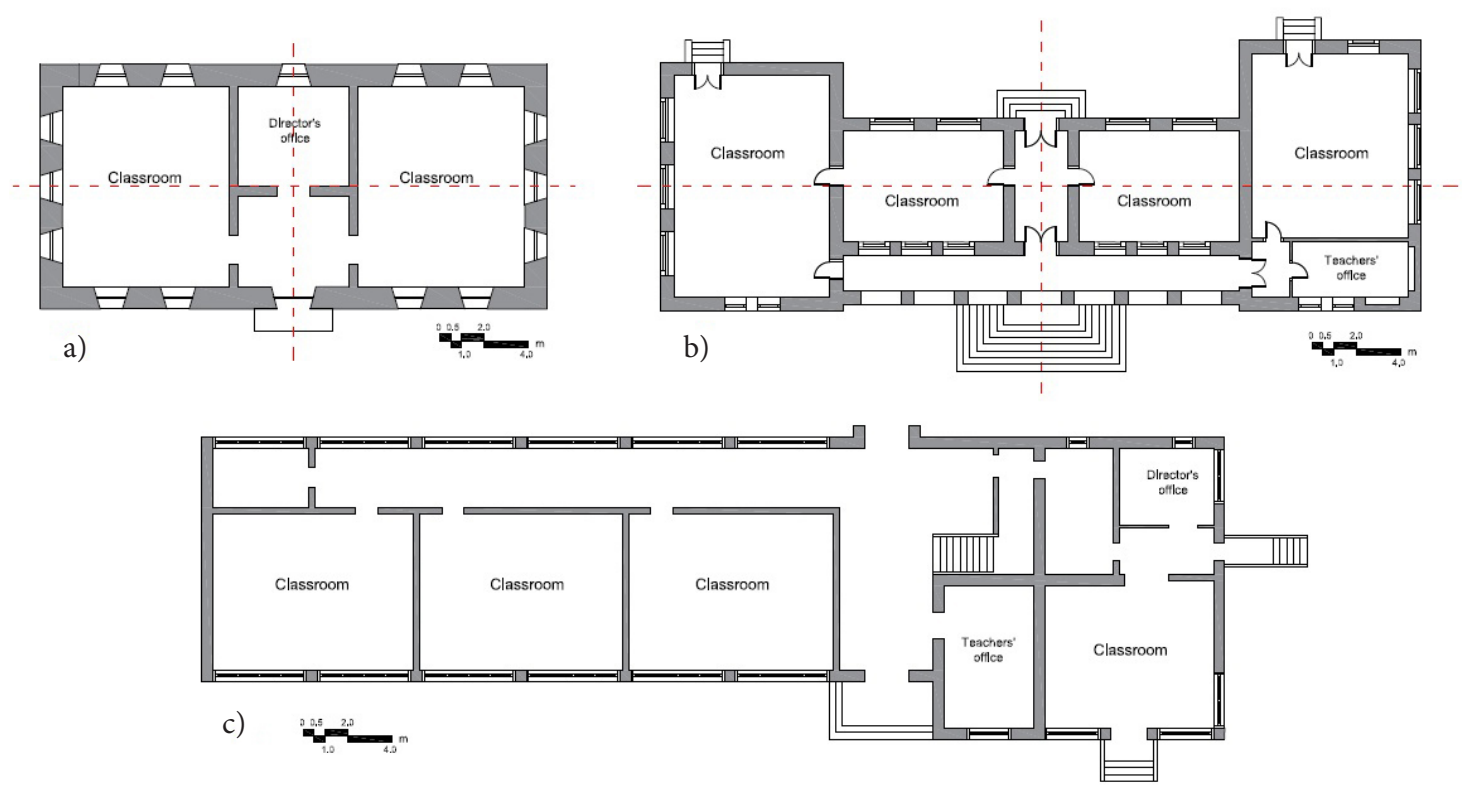

Figure 1. Depiction of the main school buildings' ground plans according to: a) Moraitis, 1880; b) Kallias (Hellenic Polytechnic Society, 1906); c) Karantinos, 1938 
abolished, since they couldn't further meet the increased needs, as well as the contemporary constructional technology (Kalafati, 1988; Lampadarios, 1928). The established Organization of School buildings proposed two building types, according to the functional needs and hygiene principles, while more than 3.000 schools were built in the period 1928-1932 (Karantinos, 1938; Kalafati, 1988). During this period, famous Greek architects undertook the design and construction of school buildings, such as D. Pikionis, P. Karantinos, N. Mitsakis (Karantinos, 1938).

The former floor plan was maintained, with the classrooms to be placed successively longwise the large side (in parallel with the corridor at the end of which there was the director's office) and the main façade was orientated to East, South-East or South (in the mountainous areas) (Figure 1c) (Lampadarios, 1928; Karantinos, 1938; Kalafati, 1988). The façades depicted the floor plan organization, which could be expanded according to the needs (in the ground or $1^{\text {st }}$ floor). The decoration of the facades was limited, with simple morphological elements, such as a perimeter band (organizing the façade in base, main body and ridge), the arched openings (with pediments or not), as well as the entrance shelter (Kalafati, 1988). The structural types applied concerned mixed type structures with the parallel use of masonry and reinforced concrete. According to Karantinos (1938), the schools of the era were constructed with a reinforced concrete frame (slabs, columns, beams).

In Figure 1, the representative ground plans of school buildings, according to Moraitis (1880), Kallias (Hellenic Polytechnic Society, 1906) and Karantinos (1938) are depicted. From the correlation of the plans, it is asserted that in the first two cases the organization of the inner spaces is symmetrical in both the elongated and vertical axis. In the latter case, classrooms were successively put alongside a corridor, located in the back of the building. The thickness of the external walls was gradually decreased (from $1 \mathrm{~m}$ to $0.5 \mathrm{~cm}$ ), while the openings' size was increased. To this direction, the constructional techniques and materials applied played an important role, as well as the presence of the reinforced concrete elements.

\section{Methodology followed}

The methodology followed, firstly concerned the record of the stone schools located in the Aristotle Municipality of Chalkidiki, N. Greece, since there was no relevant registration. Information regarding the number, exact location, as well as the initial and contemporary use of the historic buildings was assessed. To this direction, a close collaboration with the Directorate of the elementary Education of Chalkidiki, as well as the Aristotle Municipality was achieved, in order to collect historic data of the school buildings (date of erection, initial use, contemporary state and usage), as well as information on past damages. Relevant archives were evaluated, while a constant cooperation with the schools' directors was accomplished, for visits in the buildings and on-site inspection. Additionally,
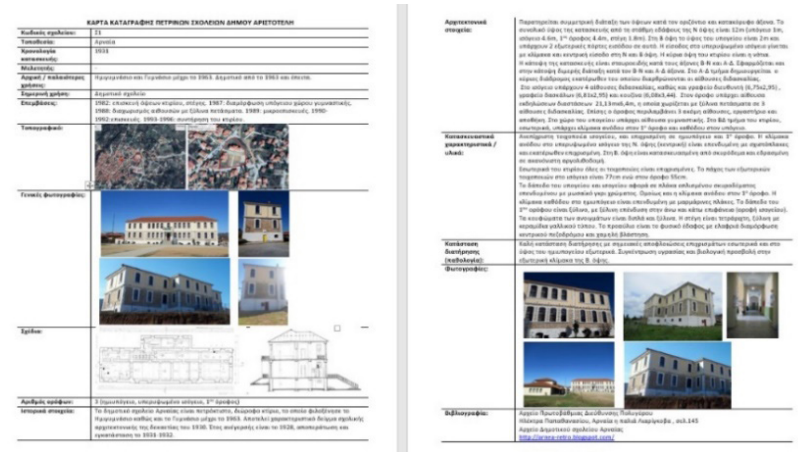

Figure 2. Card type used for the data input

collaboration was made with architects, responsible for the restoration of some buildings, in order to assess ground floor plans, as well as data concerning constructional aspects and past interventions.

The second stage concerned a detailed on-site inspection of the buildings, including photographic documentation, determination of their architectural, morphological and constructional characteristics, as well as their building materials and techniques (Pachta et al., 2021; Pachta \& Papayianni, 2017, 2019; Papayianni et al., 2016). Additionally, the preservation state of the schools was envisaged. The ground plan type, the orientation, as well as the architectural and structural aspects of the buildings, were of prior importance in order to determine the principles governing their construction.

All information was gathered in specific cards (implemented for this research) (Figure 2) that was afterwards assessed in detail. The comparative evaluation of the characteristics of all school buildings was performed, in order to envisage their similarities and differences and classify their types.

\section{Results and discussion}

\subsection{Geographical distribution of the stone schools}

The Aristotle Municipality is located in N. Greece, in the NE side of Chalkidiki peninsula. It expands in an area of around $740 \mathrm{~km}^{2}$ (population: 18.500) and constitutes of 15 settlements (Arnaia, Varvara, Neochori, Palaiochori, Stanos, M. Panagia, Stagira, Stratoniki, Stratoni, Gomati, Pyrgadikia, Ierissos, N. Roda, Olympiada, Ouranoupolis) and the small island of Ammouliani. The inner part of the Municipality is mountainous, while the Eastern part is coastal, bordering with Mount Athos. The area was inhabited by the ancient times with many of its settlements to play an important role from the Classic times and until Byzantium. Nevertheless, Aristotelis, the Great Philosopher, originated from this region and particularly from the settlement of ancient Stagira.

According to the survey, 14 stone schools are located in the Municipality, dating from 1871 to 1958 . They have been established in the settlements of Arnaia, Neochori, Palaiochori, M. Panagia, Varvara, Stanos, Stratoniki, Gomati, Pyrgadikia, Ierissos, Ouranoupolis and N. Roda. 
Additionally, there is the old stone school of the island of Amouliani, which has been erected as a Monastic settlement in 1907 and was afterwards converted to an elementary school (1925). Although mentioned, it is not further studied, since its initial construction was not for educational purposes.

In Figure 3, the geographical distribution of the stone schools is depicted. It was asserted that the earlier schools of the end of the $19^{\text {th }}$ - beginning of the $20^{\text {th }}$ century were

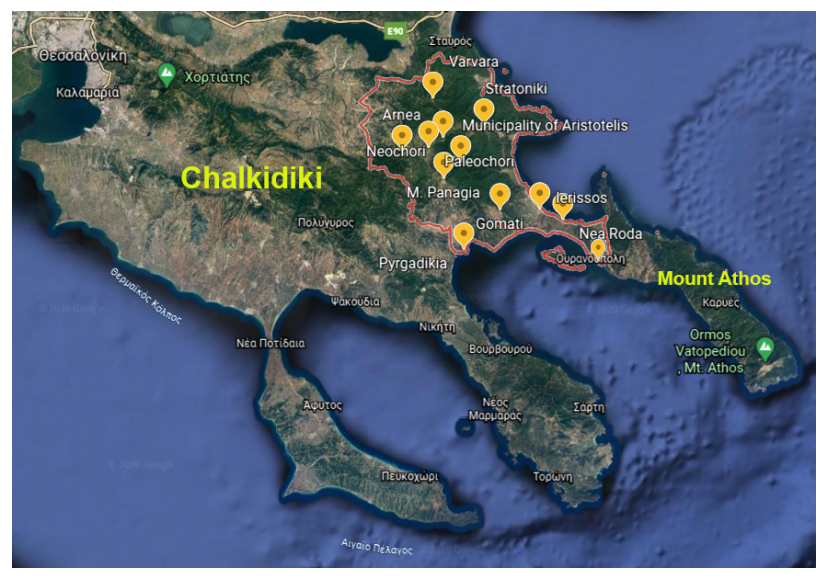

Figure 3. Geographical distribution of the stone schools of the Aristotle Municipality erected in the larger settlements (Arnaia, Stratoniki) or the most isolated ones (Varvara). Gradually and mainly after the $2^{\text {nd }} \mathrm{W}$. W., schools started to be constructed in various settlements, connected with the current road network. Generally, the school buildings were wide spread in the settlements of the region, in an inbetween distance of $5-10 \mathrm{~km}$, showing the educational priorities of the period. It could be therefore assessed that schools were important centers of each area, equally distributed in neighboring settlements, in order to be easily accessible by all pupils.

Nowadays, eight of the studied buildings are still in function as elementary schools, constituting the $57 \%$ of the total number (14) of the Municipality's elementary schools. The rest, are either abandoned or in a second use as public or cultural centers.

\subsection{Historical and architectural aspects}

The characteristics of the studied stone schools are synoptically presented Table 1, while in Figure 4 their main façades are shown. Historically, the buildings were erected in 3 eras, concerning the periods 1871-1909 (3 schools), 1922-1932 (3 schools) and 1947-1958 (8 schools). In the first era, the traditional constructional principles were applied, while in the second and third ones the guidelines given by Moraitis (1880) and Kallias (1894).
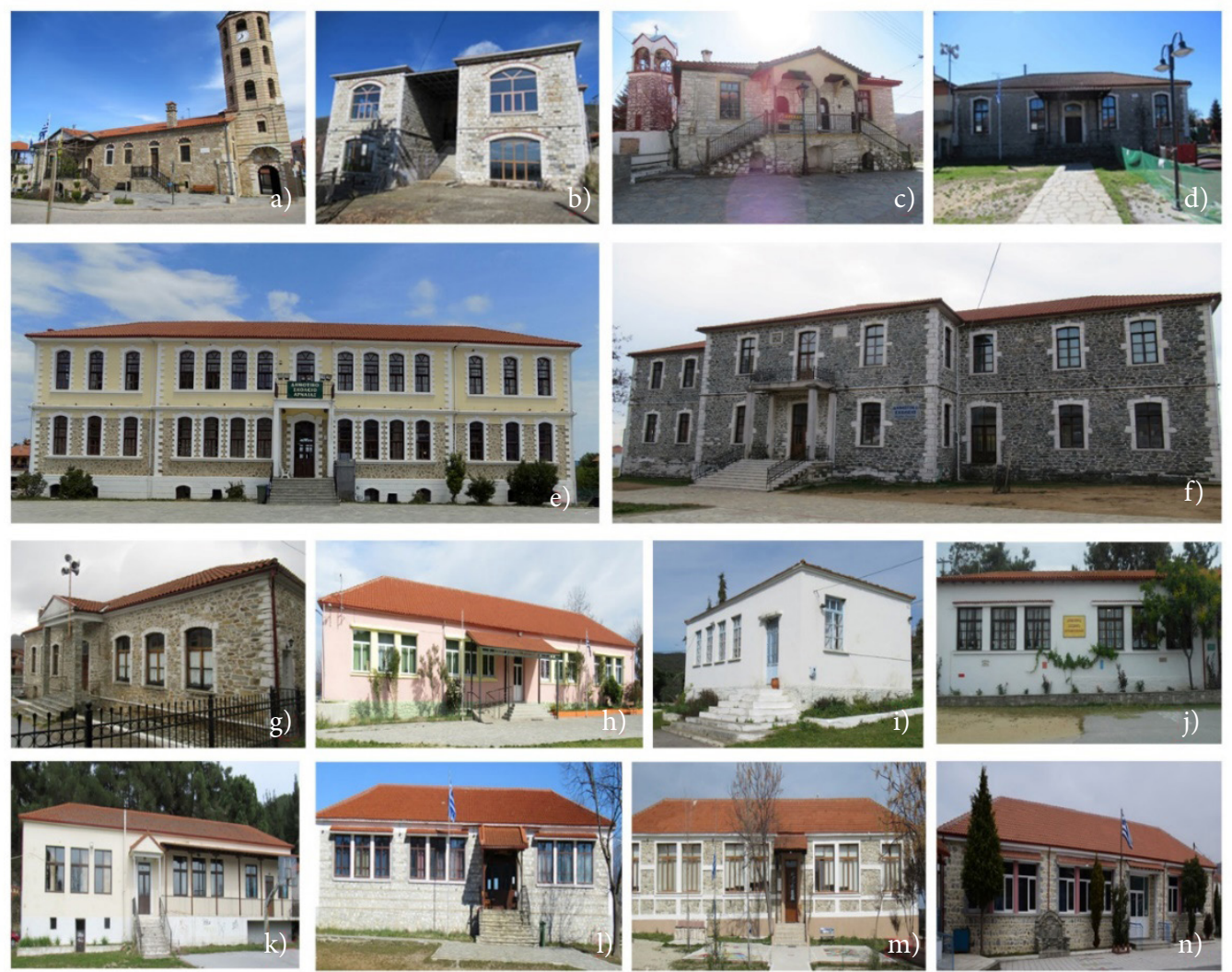

Figure 4. The stone schools of the Municipality of Aristotelis: a) Arnaia, 1871; b) Stratoniki, 1904; c) Varvara, 1909; d) Palaiochori, 1930; e) Arnaia, 1931; f) M. Panagia, 1932; g) Neochori, 1947; h) Ierissos, 1950; i) Pyrgadikia, 1951; j) Ouranoupolis, 1951; k) Gomati, 1952; l) Varvara, 1956; m) N. Roda, 1956; n) Stanos, 1958 (source: author) 
Table 1. Historical, architectural, constructional aspects of the Aristotle Municipality stone schools

\begin{tabular}{|c|c|c|c|c|c|c|c|c|}
\hline Settlement & Date & Primer use & Contemporary use & $\begin{array}{l}\text { Orienta- } \\
\text { tion }\end{array}$ & Floors $^{1}$ & $\begin{array}{c}\text { Ground } \text { plan }^{2} / \\
\text { Dimensions }\end{array}$ & $\begin{array}{l}\text { Structural } \\
\text { system }^{4}\end{array}$ & $\begin{array}{l}\text { Aspect } \\
\text { ratio }^{5}\end{array}$ \\
\hline Arnaia & 1871 & \multirow{4}{*}{$\begin{array}{c}\text { Elementary } \\
\text { school }\end{array}$} & Municipality Hall & SW & $2 / \mathrm{B}, \mathrm{G}$ & $\mathrm{R} / 13 \times 27$ & URM/ W,C & 2.1 \\
\hline Stratoniki & 1904 & & Abandoned & $\mathrm{N}$ & 3/B,G,F & C / $24 \times 28$ & URM/C & 1.2 \\
\hline Varvara & 1909 & & Multi task center & NW & $1 / \mathrm{G}$ & $\mathrm{R} / 12 \times 12.7$ & URM/C & 1.1 \\
\hline Palaiochori & 1922 & & Cultural center & $\mathrm{N}$ & $2 / \mathrm{B}, \mathrm{G}$ & $\mathrm{R} / 8.2 \times 14.2$ & URM/C & 1.7 \\
\hline Arnaia & 1931 & High school & Elem. school & SE & 3/B,G,F & SC $/ 12 \times 42.5$ & URM/W,C & 3.5 \\
\hline M. Panagia & 1932 & \multirow{9}{*}{$\begin{array}{c}\text { Elementary } \\
\text { school }\end{array}$} & Elem. school & $S$ & $3 / \mathrm{B}, \mathrm{G}, \mathrm{F}$ & SC / $11.5 \times 42$ & URM/W,C & 3.7 \\
\hline Neochori & 1947 & & Community store & SW & 2/B,G & $\mathrm{R} / 7.5 \times 23.6$ & URM/C & 3.1 \\
\hline Ierissos & 1950 & & Elem. school & $\mathrm{S}$ & $1 / \mathrm{G}$ & $\mathrm{R} / 21.5 \times 42$ & URM/C & 2.0 \\
\hline Pyrgadikia & 1951 & & Multi task center & SW & $1 / \mathrm{G}$ & $\mathrm{R} / 6.5 \times 13.5$ & URM/C & 2.1 \\
\hline Ouranoupolis & 1951 & & Elem. school & $\mathrm{S}$ & $1 / G$ & $\mathrm{R} / 8.2 \times 30.5$ & URM/C & 3.7 \\
\hline Gomati & 1952 & & Election center & $S$ & $2 / \mathrm{B}, \mathrm{G}$ & $\mathrm{R} / 7.3 \times 23.8$ & URM/C & 3.3 \\
\hline Varvara & 1956 & & Elem. school & S & $2 / B, G$ & $\mathrm{R} / 12 \times 30$ & URM/C & 2.5 \\
\hline N. Roda & 1956 & & Elem. school & S & $1 / \mathrm{G}$ & $\mathrm{R} / 8.5 \times 36$ & URM/C & 4.2 \\
\hline Stanos & 1958 & & Elem. school & $S$ & $1 / \mathrm{G}$ & $\mathrm{R} / 10.6 \times 31.7$ & $\mathrm{URM} / \mathrm{C}$ & 3.0 \\
\hline
\end{tabular}

Notes: ${ }^{1}$ Number of floors / Floor types (Semi Basement: B, ground floor: G, $1{ }^{\text {st }}$ floor: F); ${ }^{2}$ Ground plan: Rectangular: R, Semi cruciform: SC, Cruciform: $\mathrm{C} ;{ }^{3}$ Dimensions are given in $(\mathrm{m})$ and width $\times$ length $(\mathrm{w} \times \mathrm{l}) ;{ }^{4}$ Type of structural materials: walls (unreinforced masonry: URM) / floors (concrete: $\mathrm{C}$, wood: $\mathrm{W}) ;{ }^{5}$ The aspect ratio concerns the $1 / \mathrm{w}$ ratio of the rectangular plan.

The orientation of the buildings was Southern (S) or South-Western (SW), especially for the cases built after 1931 (Table 1). Prior that, orientation varied from SW to North (N) and North-Western (NW). Constructions were usually located in the back side of a large and mainly rectangular plot varying from 2.500 to $10.000 \mathrm{~m}^{2}$. When schools were located in the center of the settlement (i.e. in the main square), the land size was smaller.

In the earlier cases, as in Arnaia (1871) and Varvara (1909), schools were erected next to the central church and attached to the bell tower (Figure 5). It is interesting to notify that both bell towers were built posterior to the schools (Arnaia: 1884, Varvara: 1915). This fact confirms the close relation of the earlier schools of the region with the ecclesiastical community, according to the traditional principles followed at the end of the $18^{\text {th }}$ century (Kalafati, 1988). Although in Southern Greece the National Standards of 1881 (Moraitis, 1880; Kalafati, 1988) and 1894 (Hellenic Polytechnic Society, 1906; Kardamitsi-Adami, 1986; Pantazis, 2010) were adopted, in the region of Chalkidiki (released from the Ottoman Empire at 1912), church was still the responsible sector for school construction. The orientation of these schools seems not to be taken into account, probably due to limitations arisen from the plot size. Land was probably allocated by the church, since schools were built in the outer part of their courtyard.

In most cases, the ground plan was rectangular and dimensions $(w \times l)$ varied from $8 \times 14 \mathrm{~m}$ (Arnaia) to $21.5 \times 42 \mathrm{~m}$ (Ierissos). In the case of Stratoniki (1904), the
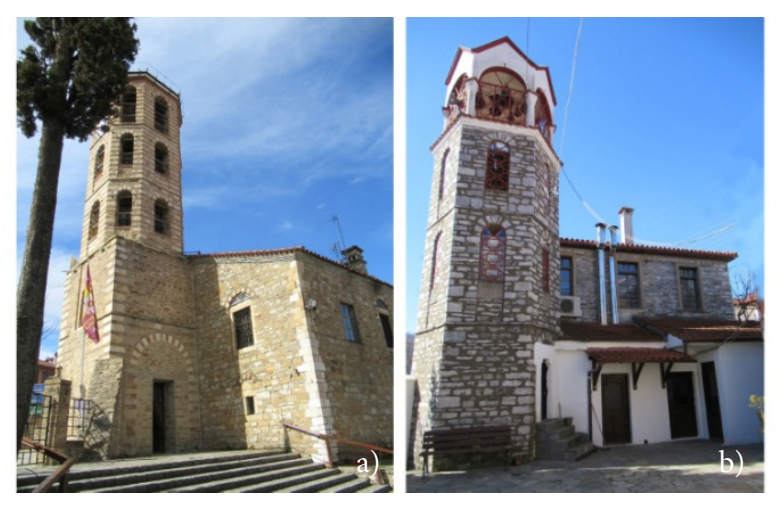

Figure 5. Attachment of the church's tower bell on the back side of the schools (pictures taken from the churches' courtyard): a) Arnaia, 1871; b) Varvara, 1909 (source: author)

ground plan was cruciform (Figure 6a), while in Arnaia (1931) and M. Panagia (1932) it could be characterized as semi-cruciform (Figure 6b, 6c). The floors ranged from 1 to 3 (basement, ground floor, $1^{\text {st }}$ floor), while in all cases the ground floor was elevated from the ground (around $0.6-1.5 \mathrm{~m}$ ).

The size of the buildings was related to the number of the classrooms needed in each settlement, ranging from 2 to 4 in the ground floor that could be also repeated in the $1^{\text {st }}$ floor. Additional spaces could be also created (i.e. director's and teachers' offices, toilets, kitchen etc.), while in the basement mainly auxiliary spaces were recorded (store rooms, toilets etc.). 


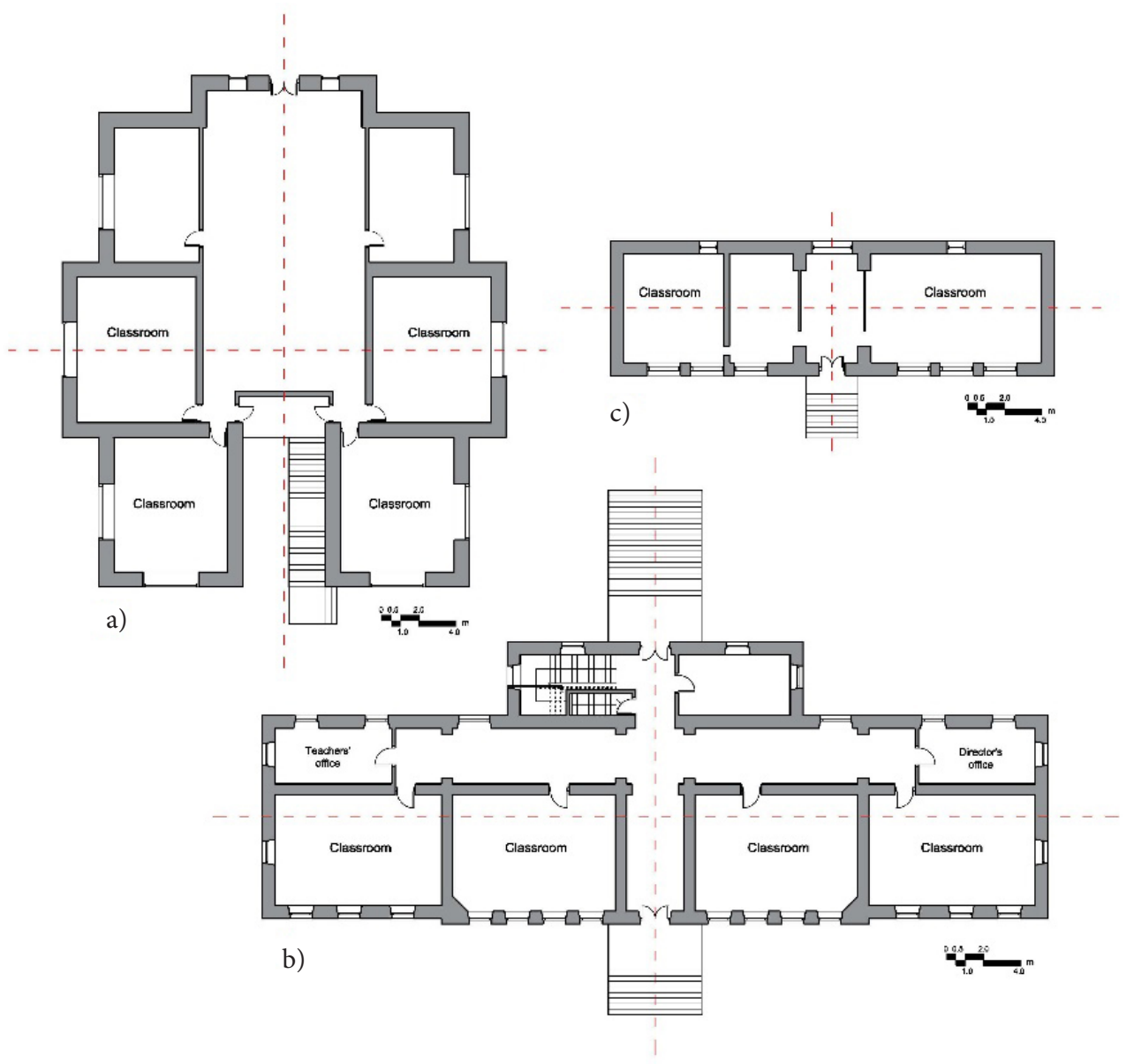

Figure 6. Typical ground plan of the stone schools of the Aristotle Municipality: a) Stratoniki, 1904; b) Arnaia, 1931; c) Gomati, 1952

As presented in Figure 6 and according to the aspect $(\mathrm{l} / \mathrm{w})$ ratio (Table 1$)$, three main ground plan types could be recorded, concerning:

- Long rectangle (aspect ratio $\geq 3$ ): Arnaia (1931), M. Panagia (1932), Neochori (1947), Ouranoupolis (1951), Gomati (1952), N. Roda (1956)

- Regular rectangle (aspect ratio 2-3): Arnaia (1871), Ierissos (1950), Pyrgadikia (1951), Varvara (1956)

- Wide rectangle (aspect ratio < 2): Stratoniki (1904), Varvara (1909), Palaiochori (1922).

According to the results, it may be asserted that in most cases, the long and regular rectangular plan was adopted (aspect ratio $>2$ ), while the wide rectangular (aspect ratio <2) was mainly found in the period 1904-1922. To this, other parameters could be also related, such as the requirements and capacity of schools that in many cases met the needs of the neighboring settlements.

Classrooms were usually rectangular, with dimensions mainly around $6 \times 9 \mathrm{~m}$ that were in cases divided with wooden plates. They were usually placed with their wide side alongside the main façade, where they had consecutive openings. As presented in Figure 6, in the case of a small school with 2 classrooms (Figure $6 \mathrm{c}$ ), these were put on the left and right side of the building, symmetrically to a transversal central corridor (with the central entrance) that led to the director's office. In larger buildings, classrooms were put across an elongated corridor (located in the back side) and bilateral to the transversal corridor that led to the main entrance (Figure $6 b, 7 a, 7 c$ ). In case of a second floor, the stair case was put on the backside of the building (Figure 7b). Generally, there was a symmetric organization of the floor plan in both the elongated and vertical axis.

The openings were symmetrically put in the facades, depicting the inner organization of the spaces, according to relevant studies (Martinez-Molina et al., 2017; Perrone et al., 2020). Their dimensions $(\mathrm{h} \times \mathrm{w})$ could vary (1-1.25 $\times 1.5-2.4 \mathrm{~m})$ and their shape was either rectangular or slightly arched (Figure 8). In other cases, an arched relief existed beyond the window, as in the case of Arnaia (1871) (Figure 8a) (Pachta et al., 2021). Their type, dimensions, as well as their in-between distance were stable in each façade. They were usually decorated with a perimetrical frame, made of stone (Figure $8 \mathrm{a}, 8 \mathrm{c}$ ) or mortar layers (Figure $8 \mathrm{~b}$ ) that also ensured their form and stability.

Other decorative elements, such as the perimetric horizontal stripes that vertically divided facades in three parts (base, main body, ridge) (Figure 8b), the ashlar 

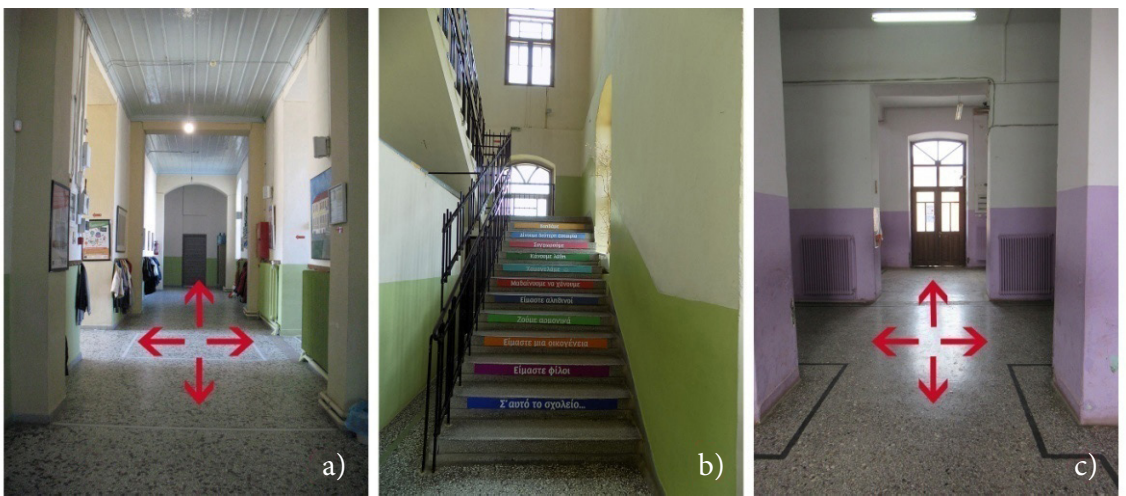

Figure 7. Figures of the inner space of stone schools: a-b) Arnaia, 1931. The elongated corridor of the ground floor, connected with the transversal one; c) M. Panagia, 1932. The transversal corridor of the ground floor (leading to the main entrance), connected with the elongated one (source: author)
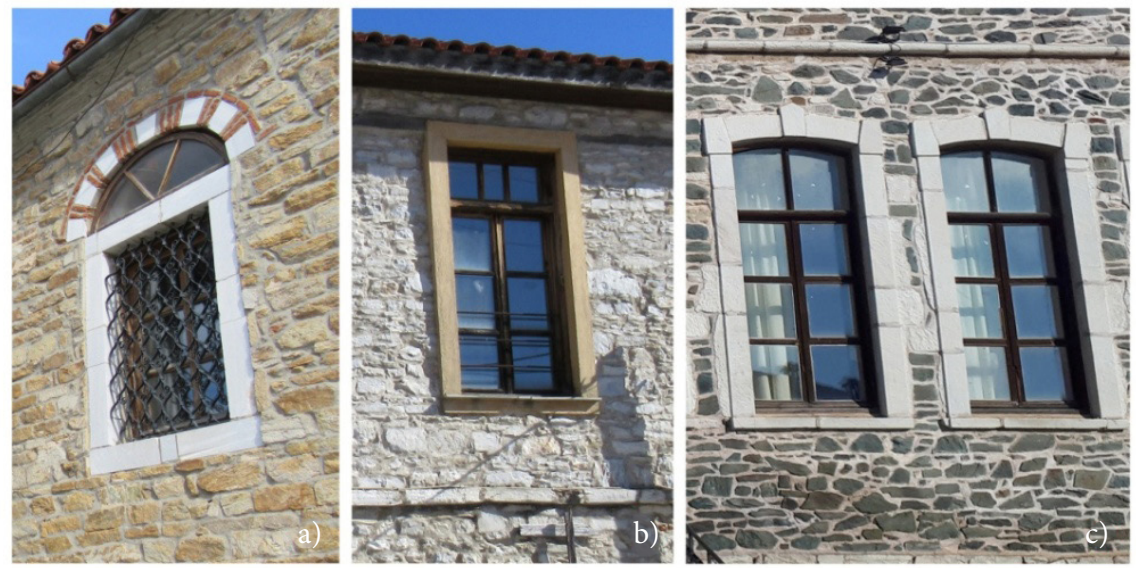

Figure 8. Openings' types of the stone schools: a) Arnaia, 1871; b) Varvara, 1909; c) M. Panagia, 1932 (source: author)
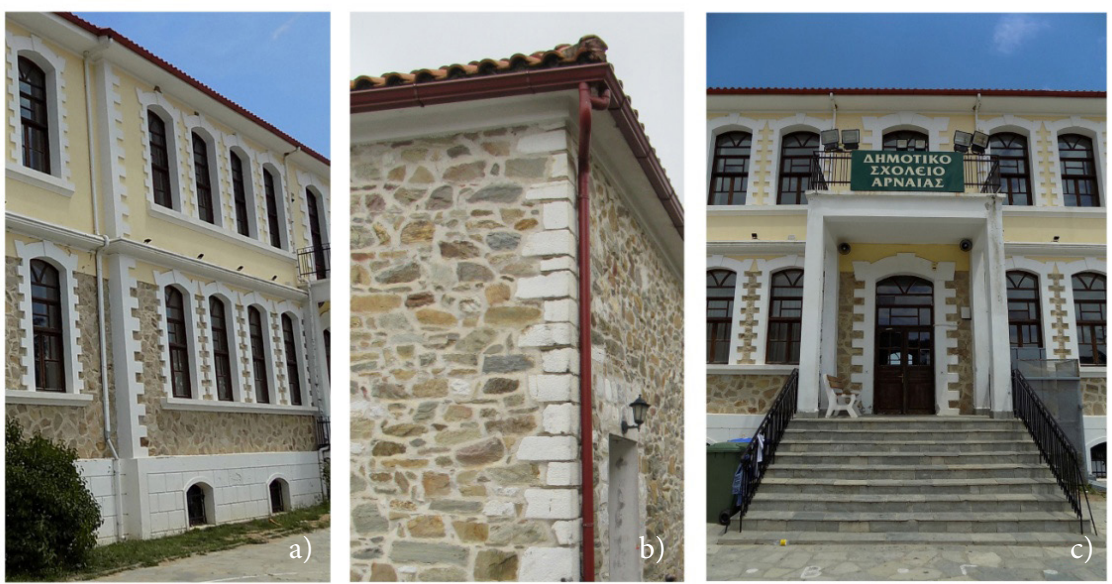

Figure 9. Other architectural aspects: a) Perimetric horizontal stripes in Arnaia, 1931; b) Ashlar cornerstones in Neochori, 1947; c) Central entrance shelter in Arnaia, 1931 (source: author) 
cornerstones (Figure 9a), as well as the entrance shelters (Figure 9b) met both constructional and functional needs. Generally, the morphological means of the buildings were very limited (externally as in the inner space) and were governed by the principle of simplicity. Their structural integrity and functionality prevailed, forming rigorous constructions, distinguished for their role in society, as testified by relevant studies (Abreu Marques et al., 2015; Perrone et al., 2020; Martinez-Molina et al., 2017; Khledj \& Bencheikh, 2021).

Generally, it could be asserted that there were many similarities governing the architecture of the studied school buildings, although they were built in an era of almost 90 years, where significant innovations were implemented in the constructional sector. They were all based on traditional building techniques, concerning thick stone walls arranged in a symmetric ground plan, with successive large openings. The latter, ensured natural ventilation and lighting, whereas the thick walls and successive layers of renders and plasters, adequate thermal insulation. Additionally, the orientation of the main facades in the S / SW, maximized solar gain at such mountainous cold climates, enhancing energy efficiency. The development of the facades followed the ground plan, depicting the arrangement of the inner spaces, while decorative elements highlighted the inner construction.

Although from 1930 and on, school planning in Greece was based on the modern architectural principles (according to the relevant law of 1929), it was noticed that in the regional area of N. Greece (and until 1958), schools were still built according to tradition, by following previous legislative frames and technical guidelines $(1880,1894)$. In all cases, the building envelope depicted the use and functional role of the structures, which were erected in central and easily accessible areas of the settlements. They were therefore treated as important assets of the community, comprising of educational and cultural landmarks.

The differences foreseen, concerned mainly the floor number (one to three), as well as the dimensions of the rectangular ground plans, which ranged from $6.5 \times 13.5 \mathrm{~m}$ to $21.5 \times 42 \mathrm{~m}$. As has been stated, the long and regular rectangular plan was usually found, while the wide rectangular plan was adopted during 1904-1922, probably for the better exploitation of the limited land.

\subsection{Constructional aspects}

As presented in Table 1, the structural system of all buildings was mixed type, concerning the combined used of unreinforced masonry, wood and concrete. In the earliest cases, such as in Arnaia (1871) and Stratoniki (1904) (probably until 30's), the nowadays found concrete elements (slabs, beams) were added during repair works, implemented either in the 60's or later. This has been testified through testimonials and historic archives of the schools. However, from 1930 and on the mixed type system was adopted and concrete elements seemed to function supplementary to the masonry mass, according to relevant findings (Abreu Marques et al., 2015; Perrone et al., 2020; Pachta et al., 2021).

In these cases and until the end of the 60's, the slab of the ground floor was made by reinforced concrete, directly supported on the masonry walls of the semi-basement. Underneath, consecutive concrete beams, ordered widthwise the ground plan, supported the structure (Figure 10a). The slab was covered with the traditional polished cement mosaic (Figure 7), found in many contemporary or posterior buildings (Abreu Marques et al., 2015; Perrone et al., 2020; Pachta \& Papayianni, 2017, 2019). In the earlier examples of Arnaia (1931) and M. Panagia (1932), the concrete slab of the ground floor was extended only in the corridors, while the classrooms' floor was made of wood. The staircase was also made of reinforced concrete (Figure $7 \mathrm{~b}$ ), as well as a small part of the $2^{\text {nd }}$ floor's corridor (the rest was made of wood) (Figure 10b). In the masonry walls, consecutive pillars extending throughout their whole height enhanced constructions (Figure 10c). They were symmetrically put in the external, as well as
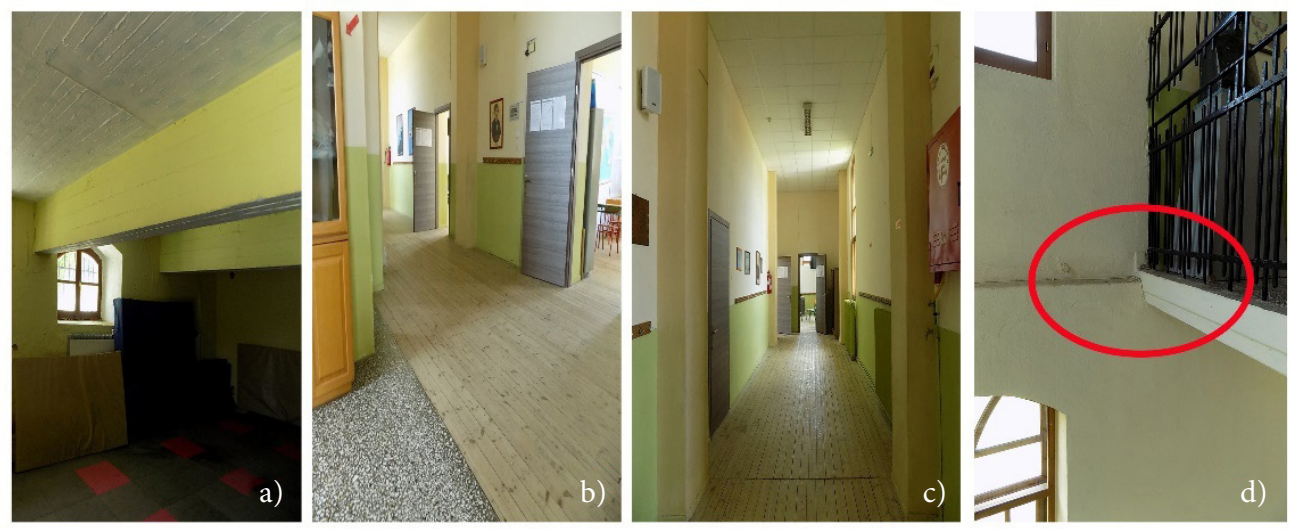

Figure 10. Constructional aspects of the stone school in Arnaia, 1931: a) Concrete slab and beams of the ground floor (image from the basement); b) Concrete slab part and wooden floor of the $1^{\text {st }}$ floor; c) Consecutive pillars of the $1^{\text {st }}$ floor; d) Setting of the $1^{\text {st }}$ floor concrete slab on the wall recession of the ground floor (source: author) 
in the internal (in the side of the corridor) walls, in an intermediate distance of around 6-7 m.

In the one story schools (mainly built from 1950 and on), the concrete slab was extended in the whole plan. It was based on the external walls that were elevated from the ground level $(0.6-1.5 \mathrm{~m})$. The roofs in all cases were wooden, with ceramic tiles, as well as the ceilings' covering.

The thickness of both the external and internal walls was reduced throughout their height: the external ranged from $70-85 \mathrm{~cm}$ (basement), to $65-75 \mathrm{~cm}$ (ground floor) and $50-60 \mathrm{~cm}$ (first floor) and the internal from $60-75 \mathrm{~cm}$ to $60-70 \mathrm{~cm}$ and $50-55 \mathrm{~cm}$ respectively. The external walls' recession, throughout the building height, visible in the part of the staircase, is presented in Figure 10d.

Semi-ashlar or rubble masonry prevailed with semishaped or angular stones of local origin (Figure 11). Their size varied $(10-20 \times 20-40 \mathrm{~cm})$ and their origin was mainly calcitic or igneous (Figure 11). The joints' thickness also varied from 2 to $4 \mathrm{~cm}$ (according to the masonry type) and probably referred to lime-based mortars, according to former research work (Pachta \& Papayianni, 2016, 2017; Papayianni et al., 2016). Externally, especially in the case of ruble masonry, the walls were rendered with successive mortar layers, whose thickness was reduced to the surface, while in the internal, all walls were plastered.

External walls were usually connected with horizontal metallic beams that run throughout the side length. In some cases, external metallic joints were observed in each floor level (Figure 11b).

According to the research results, the structures concerned stone masonry, with wooden (i.e. floors) and metallic elements. Pillars, symmetrically located in the ground plan, enhanced structural integrity, as well as a supplementary use of concrete, regarding a concrete slab mainly in the ground floor and internal beams. Building materials were of local origin, selected and applied in a way to achieve maximum quality, which was enhanced by the symmetric allocation of the inner spaces. The on height decrease of the walls' thickness, as well as the large successive openings, enlightened constructions, ensuring their capacity and preservation.
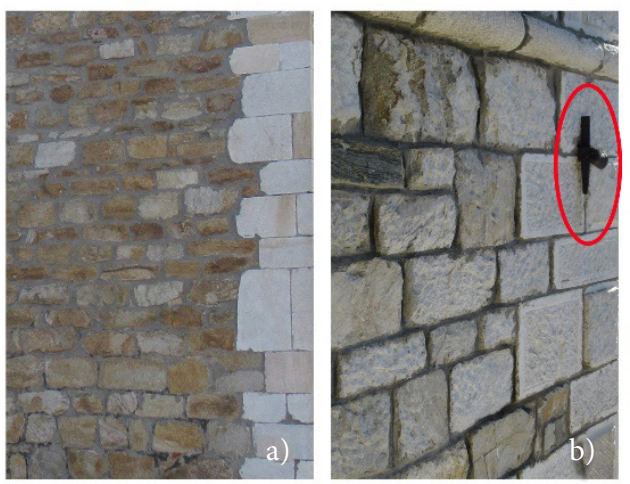

Generally, it could be stated that sustainability criteria were applied for the erection of these constructions, focusing on both minimizing the cost and increasing their integrity and performance, by exploiting the diachronic constructional principles and the expertise of local masons.

\subsection{Preservation state and general remarks}

Regarding the preservation state of these buildings, it should be noticed that they were generally in good condition. The pathology symptoms confronted mainly regarded the building materials themselves, without affecting the stability and bearing capacity of the structures. Their overall state could be attributed to variable factors, as following:

Structural aspects: although stone schools were built according to traditional techniques and materials, raw materials were carefully selected and applied in order to be durable and cost-effective (Arya, 1987; Abreu Marques et al., 2015; Perrone et al., 2020; Pachta \& Papayianni, $2017,2019)$. The physiognomy and educational character of the buildings emerged the need to be resistant to various actions (i.e. environmental parameters, seismic loads etc.), since the students' safety was the primer goal. To this direction, the supplementary use of concrete elements played an important role. Additionally, the symmetric organization of the ground plan, as well as of the openings, lessened the structure's vulnerability, while the elevation of the ground floor decreased the ascending humidity from the ground. Other parameters, such as the stoney openings' frames, as well as the enhanced cornerstones and the vertical pillars strengthened constructions.

Interventions: stone schools were subjected to consecutive repair works throughout their service life. They focused either on enhancing their structural stability and integrity, as in the old school of Arnaia (1871) that was almost demolished during the 80's and extensive repair works were implemented, or restoring damages that arose (i.e. cracks, detachment of renders-plasters, corrosion of external joints, openings' frames replacement). In most cases, works regarding energy upgrading occurred, as well as replacement of the traditional mortars (joints, renders, plasters) with cement based ones.
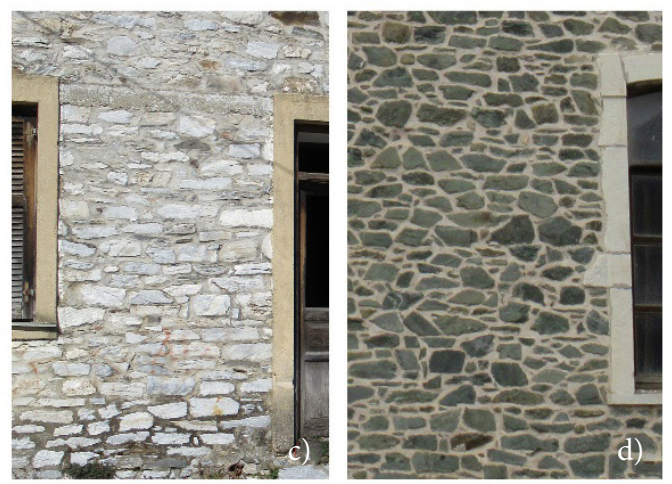

Figure 11. Masonry types of the stone schools: a) Arnaia, 1871;

b) Stratoniki, 1904; c) Varvara, 1909; d) M. Panagia, 1932 (source: author) 
Social aspects: old schools were usually landmarks of each community, as in the case of the churches and authority centers. Citizens were always attached to the values incorporated in them, since they reflected their childhood. As a result, they were often involved in their preservation and repair, as in the case of the old school of Arnaia (1871) that the citizens' efforts and means overturned the Authorities' decision for demolition (due to severe damages).

Another parameter that needs to be discussed is the stone schools' ownership, since from their erection and until nowadays, they belong to various sectors. In Greece, they firstly belonged to the church, afterwards to the central state and nowadays in Municipalities that are also responsible for their preservation. There are only few examples of schools that have been listed and acknowledged as part of our architectural heritage (which are in a second use), such as in Arnaia (1871) and Stratoniki (1904), while in the rest no relevant action is anticipated.

The interventions that took place during their service life, mainly focused on meeting the urgent needs of functionality and use, slightly taking into account their historic, technological, architectural and constructional values. Since this part of the common architectural heritage has not been yet adequately acknowledged, it is often difficult to apply the principles governing the preservation and proper restoration of monuments. As a result, authentic structural elements are being vanished, while inproper repair materials and techniques are applied.

\section{Conclusions}

Historic schools, apart from their diachronic role as educational centers, constitute a significant part of our common architectural heritage that has not been yet adequately acknowledged. Their structure and physiognomy was evolved during the last 3 centuries, however constantly focusing on their functional requirements and educational role. In the case of the stone schools of the Aristotle Municipality in Chalkidiki, Greece, they continued to be built according to traditional materials and techniques even after the $2^{\text {nd }} \mathrm{W}$. W., despite the relevant specifications existing in the Greek state from the beginning of the $20^{\text {th }}$ century.

Their structure presents many similarities, concerning both their constructional and architectural aspects, mainly governed by their functional role and the structural safety requirements. They concerned distinct constructions, with limited decorative elements, whose ground plan was symmetrically organized. Raw materials of local origin were applied, while supplementary elements of reinforced concrete enhanced their stability. Their current condition is generally in a good state, due to the consecutive interventions implemented during their service life.

The protection and preservation of historic schools is a perspective that needs to be taken into consideration, since they mostly concern vivid constructions, with an important impact on the everyday life of each community. The tangible and intangible values they incorporate should be also assessed, in order to be conveyed into the next generations. To this direction, their identification as heritage assets should be processed, in order for their contemporary (and future) use and repair to follow the principles of restoration and rehabilitation of monuments.

\section{References}

Abreu Marques, B., de Brito, J., \& Correia, J. R. (2015). Constructive characteristics and degradation condition of Liceu secondary schools in Portugal. International Journal of Architectural Heritage, 9(7), 896-911.

https://doi.org/10.1080/15583058.2013.865814

Arya, A. S. (1987). Protection of educational buildings against earthquakes, a manual for designers and builders (Educational Building Report No. 13). Bankok, Unesco.

Atkins, R. (1999). The repair and conversion of Norton Park School, Edinburgh: A sustainable future for a historic building. Journal of Architectural Conservation, 5(1), 7-23. https://doi.org/10.1080/13556207.1999.10785232

Augustinaite, D. (2018). Challenges of innovative architecture: Education and practice. Journal of Architecture and Urbanism, 42(1), 63-69. https://doi.org/10.3846/jau.2018.1989

Avrami, E., Mason, R., \& de la Torre, M. (2000). Values and heritage conservation (Research Report). The Getty Conservation Institute.

Broekhuizen, D., Arkesteijn, M., De Jong, P., \& van Nieuwamerongen, F. (2020). Conversion strategies for Dutch primary schools: Practice and refinement. Journal of Architecture and Urbanism, 44(1), 69-77. https://doi.org/10.3846/jau.2020.11448

Buvik, K., Andersen, G., \& Tangen, S. (2014). Ambitious renovation of a historical school building in cold climate. Energy Procedia, 48, 1442-1448.

https://doi.org/10.1016/j.egypro.2014.02.163

Camacho-Montano, S. C., Cook, M., \& Wagner, A. (2020). Avoiding overheating in existing school buildings through optimized passive measures. Building Research \& Information, 48(4), 349-363. https://doi.org/10.1080/09613218.2019.1663137

Carofilis, W., Perrone, D., O’Reilly, G. J., Monteiro, R., \& Filiatrault, A. (2020). Seismic retrofit of existing school buildings in Italy: Performance evaluation and loss estimation. Engineering Structures, 225, 111243.

https://doi.org/10.1016/j.engstruct.2020.111243

Dascalaki, E. G., \& Sermpetzoglou, V. G. (2011). Energy performance and indoor environmental quality in Hellenic schools. Energy and Buildings, 43(2-3), 718-727. https://doi.org/10.1016/j.enbuild.2010.11.017

Douglas-Jones, R., Hughes J. J., Jones S., \& Yarrow, T. (2016). Science, value and material decay in the conservation of historic environments. Journal of Cultural Heritage, 21, 823-833. https://doi.org/10.1016/j.culher.2016.03.007

Doukas, D. I., \& Bruce, T. (2017). Energy audit and renewable integration for historic buildings: The case of Craiglockhart Primary School. Procedia Environmental Sciences, 38, 77-85. https://doi.org/10.1016/j.proenv.2017.03.081

François, L. (1968). The right to education: From proclamation to achievement 1948-1968. Unesco.

Freeman, K. J. (1912). Schools of Hellas: An essay on the practice and theory of ancient Greek education from 600 to 300 B.C. (M. J. Rendall, Ed.). Macmillan and Co Limited. 
Galimullina, A., \& Korotkova, S. (2020). Adapting the architecture of school buildings in the context of humanizing the environment. IOP Conference Series: Materials Science and Engineering, 890, 012008.

https://doi.org/10.1088/1757-899X/890/1/012008

García, I. (2020). Repurposing a historic school building as a teacher's village: Exploring the connection between school closures, housing affordability, and community goals in a gentrifying neighbourhood. Journal of Urbanism: International Research on Placemaking and Urban Sustainability, 13(2), 153-169. https://doi.org/10.1080/17549175.2019.1626265

Guarini, M. R., Morano, P., \& Sica, F. (2020). Historical school buildings. A multi-criteria approach for urban sustainable projects. Sustainability, 12, 1076.

https://doi.org/10.3390/su12031076

Hellenic Polytechnic Society. (1906). The Paris Conference on the hygiene of buildings. The Greek measures for the hygiene of school buildings. Archimedes, 2, 13-18 (in Greek).

Kalafati, E. (1988). The school buildings of the elementary education 1821-1929. In Historic archives of Greek youth. General Secretariat for Youth (in Greek).

Karantinos, P. (1938). The new school buildings. Technical Chamber of Greece (in Greek).

Kardamitsi-Adami, M. D. (1986). Kallias and the school building. National Technical University of Athens (in Greek).

Khledj, S., \& Bencheikh, H. (2021). Impact of a retrofitting project on thermal comfort and energy efficiency of a historic school in Miliana, Algeria. International Journal of Architectural Heritage, 15(3), 407-425. https://doi.org/10.1080/15583058.2019.1621960

Kokkonis, I. P. (1831). Summary of the report given to the commission on primary instruction concerning the manual for the mutual-method schools of France (J. Sarazin, Ed.). Egina (in Greek).

Lampadarios, E. (1928). School hygiene (2nd ed.). Sfendonis Publishers (in Greek).

Lassandro, P., Cosola T., \& Tundo, A. (2015). School building heritage: energy efficiency, thermal and lighting comfort evaluation via virtual tour. Energy Procedia, 78, 3168-3173. https://doi.org/10.1016/j.egypro.2015.11.775

Lee, J., Kim, J., Ahn, J., \& Woo, W. (2019). Context-aware risk management for architectural heritage using historic building information modeling and virtual reality. Journal of Cultural Heritage, 38, 242-252. https://doi.org/10.1016/j.culher.2018.12.010

Lerma, C., Mas, A., \& Blasco, V. (2013). Analysis procedure of a previous planning organization: The area of the Seminary School of Corpus Christi in Valencia, Spain. International Journal of Architectural Heritage, 7(2), 135-152. https://doi.org/10.1080/15583058.2011.624252

Martinez-Molina, A., Boarin, P., Tort-Ausina, I., \& Vivancos, J. L. (2017). Post-occupancy evaluation of a historic primary school in Spain: Comparing PMV, TSV and PD for teachers' and pupils' thermal comfort. Building and Environment, 117, 248-259. https://doi.org/10.1016/j.buildenv.2017.03.010
Moraitis, S. (1880). Educational method: Instructions for the use of the new educational method (Vlastou ed.). Library of the Association for the Diffusion of Greek Letters, Association for the Dissemination of Greek Letters, Athens (in Greek).

Pachta, V., \& Papayianni, I. (2016). Design and application of a data system for the comparative study of historic mortars. In Lecture notes in computer science: Vol. 10058. Digital heritage. Progress in cultural heritage: Documentation, preservation, and protection (pp. 701-710). Springer.

https://doi.org/10.1007/978-3-319-48496-9_56

Pachta, V., \& Papayianni, I. (2017). The study of the historic buildings of Eclecticism in Thessaloniki under the prism of sustainability. Procedia Environmental Sciences, 38, 274-282. https://doi.org/10.1016/j.proenv.2017.03.078

Pachta, V., \& Papayianni, I. (2019). Study of the building materials and techniques of mixed-type structures from the nineteenth to the twentieth century. In 10th International Symposium on the Conservation of Monuments in the Mediterranean Basin, Natural and Anthropogenic Hazards and Sustainable Preservation (pp. 407-413). Springer.

https://doi.org/10.1007/978-3-319-78093-1_43

Pachta, V., Terzi, V., \& Malandri, E. (2021). Architectural, constructional and structural aspects of a historic school in Greece. The case of the elementary school in Arnaia, Chalkidiki. Heritage, 4, 1-19. https://doi.org/10.3390/heritage4010001

Pantazis, C. (2010). Mass education and economic development in Greece: The educational reform of 1929 [Dissertation, University of Ioannina]. Department of Early Childhood Education, Ioannina (in Greek).

Papayianni, I., Pachta, V., \& Milosi, A. (2016). The survey of a historical building from the beginning of the previous century. Evaluation of mechanical characteristics of the load bearing system. In Concrete Solutions - Proceedings of Concrete Solutions, 6th International Conference on Concrete Repair (pp. 353-360). Thessaloniki.

Perrone, D., O’Reilly, G. J., Monteiro, R., \& Filiatrault, A. (2020). Assessing seismic risk in typical Italian school buildings: From in-situ survey to loss estimation. International Journal of Disaster Risk Reduction, 44, 101448. https://doi.org/10.1016/j.ijdrr.2019.101448

Tipei, A. R. (2017). How to make friends and influence people: Elementary education, French "influence," and the Balkans, 1815-1830s. Modern Intellectual History, 15(3), 621-649. https://doi.org/10.1017/S147924431700018X

United Nations General Assembly. (1948, December 10). Universal Declaration of Human Rights (UDHR) (General Assembly resolution 217 A). Paris.

Watters, D. M. (2020). Our Catholic school: themes and patterns in early Catholic school buildings and architecture before 1872. The Innes Review, 71(1), 1-66.

https://doi.org/10.3366/inr.2020.0244 